Keywords:

F-Area Tank Farm

Tank 18-F

Wall Samples

Retention: permanent

\title{
RECOMMENDATIONS FOR ASSESSING THE UNCERTAINTY IN TANK 18-F WALL SAMPLES
}

E.P. Shine

October 26, 2010

Applied Computational Engineering and Statistics Savannah River National Laboratory

Aiken, SC 29808

This document was prepared in conjunction with work accomplished under Contract No. DE-AC09-08SR22470 with the U.S. Department of Energy.

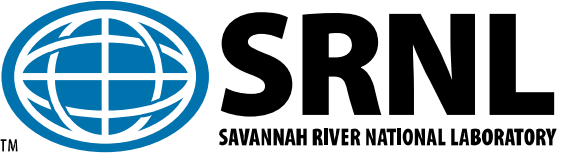




\section{DISCLAIMER}

This work was prepared under an agreement with and funded by the U.S. Government. Neither the U.S. Government or its employees, nor any of its contractors, subcontractors or their employees, makes any express or implied: 1 . warranty or assumes any legal liability for the accuracy, completeness, or for the use or results of such use of any information, product, or process disclosed; or 2. representation that such use or results of such use would not infringe privately owned rights; or 3. endorsement or recommendation of any specifically identified commercial product, process, or service. Any views and opinions of authors expressed in this work do not necessarily state or reflect those of the United States Government, or its contractors, or subcontractors.

This document was prepared in conjunction with work accomplished under Contract No. DE-AC09-08SR22470 with the U.S. Department of Energy. 


\section{RECOMMENDATIONS FOR ASSESSING THE UNCERTAINTY IN TANK 18-F WALL SAMPLES}

E.P. Shine

October 26, 2010

Computational Sciences

Savannah River National Laboratory

Aiken, SC 29808

This document was prepared in conjunction with work accomplished under Contract No. DE-AC09-08SR22470 with the U.S. Department of

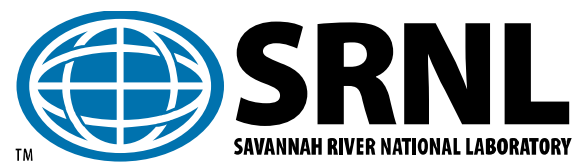
Energy. 


\section{AUTHORS:}

E.P. Shine, Applied Computational Engineering and Statistics

Date

Savannah River National Laboratory

\section{TECHNICAL REVIEWERS:}

S.P. Harris, Applied Computational Engineering and Statistics

Date

Savannah River National Laboratory

\section{APPROVERS:}

F. M. Pennebaker, Manager, Advanced Characterization \& Processing Date Savannah River National Laboratory

W.B. Dean, Closure and Disposal Assessment

Date Savannah River Remediation

G.D. Thaxton, Closure Project Engineering

Date Savannah River Remediation

P.L. Lee, Applied Computational Engineering and Statistics

Date

Savannah River National Laboratory 


\section{TABLE OF CONTENTS}

Executive Summary

PAGE

1.0 Introduction vii

2.0 Available Sample Information............................................................................... 3

3.0 Radionuclide Concentrations ............................................................................... 5

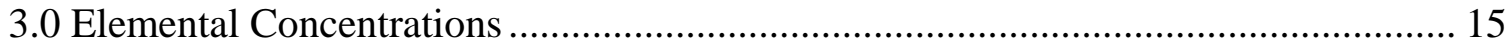

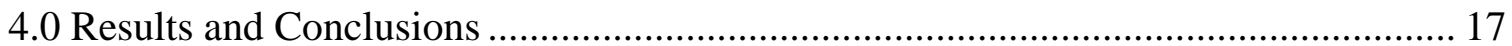

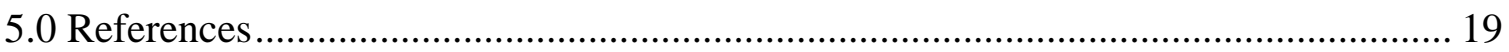

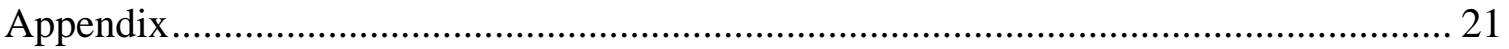

\section{LIST OF TABLES}

Table 1. Analyte Concentrations Measured on at Least One Sample from Each Location 3

Table 2. Analytes having Measured Concentrations on the Scale Sample and Floor Samples, but not the Upper or Lower Wall Samples

Table 3. Analyte Concentrations Measured on Wall or Scale Samples but not on Floor Samples.

Table 4. Analyte Concentrations Measured on Floor Samples but not any Wall or Scale Samples...................................................................................................... 4

Table 5. Radionuclide Concentrations ( $\mu \mathrm{Ci} / \mathrm{g}$ ) by Wall Sample Location ........................... 9

Table 6. 95\% Upper Confidence Bands (UCL-Mean) for Radionuclides ......................... 12

Table 7. 95\% Upper Confidence Bands (UCL-Mean) of the Mean Analyte Concentration per g by Location.......................................................................................... 12

Table 8. 95\% Upper Confidence Bounds for Concentration per unit mass (g) at Individual Wall Sample Locations (Tank Heights)............................................... 13

\section{LIST OF FIGURES}

Figure 1. Plot of the Radionuclide Concentrations per Unit Area $\left(\mu \mathrm{Ci} / \mathrm{ft}^{2}\right)$ for the Upper Wall and the Lower Wall Samples

Figure 2. Plot of the Percent Differences between the Radionuclide Concentrations per Unit Area $\left(\mu \mathrm{Ci} / \mathrm{ft}^{2}\right)$ for the Upper Wall and the Lower Wall Sample

Figure 3. Plot of the Analyte Radionuclide Concentrations per Gram of Sampled Material $(\mu \mathrm{Ci} / \mathrm{g})$ for the Upper Wall and the Lower Wall Samples.

Figure 4. Plot of Percent Differences between the Radionuclide Concentrations per Gram of Sampled Material $(\mu \mathrm{Ci} / \mathrm{g})$ for the Upper Wall and the Lower Wall Samples.. 7

Figure 5. Studentized Radionuclide Concentrations per Gram of Sampled Material $(\mu \mathrm{Ci} / \mathrm{g})$ for the Upper Wall, the Lower Wall, and the Scale Samples. 10

Figure 6. Studentized Non-radionuclide Concentrations per Gram of Sampled Material for the Upper Wall, the Lower Wall, and the Scale Samples ( $\mu \mathrm{g} / \mathrm{g})$. 16 
Recommendations for Assessing the Uncertainty in Tank 18-F Wall Samples

SRNL-STI-2010-00525, Rev. 1

October 26, 2010

This Page is Intentionally Blank 


\section{EXECUTIVE SUMMARY}

Tank 18-F in the F-Area Tank Farm at the Savannah River Site (SRS) has had measurements taken from its inner vertical sides in order to determine the level of radionuclide and other analyte concentrations attached to the tank walls. In all, three samples have been obtained by drilling shallow holes into the carbon steel walls and consolidating the material. An Upper Wall Sample (Sample ID: Tk 18-1) was formed by combining two drill samples taken at a height of $17 \mathrm{ft}$ above the tank floor, and a Lower Wall Sample (Sample ID: SPD4) was formed by combining two drill samples taken between 10 and $12 \mathrm{ft}$ above the tank floor. A Scale Sample (Sample ID: Tk 18-2) was formed by combining 5 drill samples obtained between 6 and $7 \mathrm{ft}$ above the tank floor. Photographs of the sampled material and a more detailed description of the samples and the concentration results are presented by Hay and others [2009].

The objective of this report is to determine a method and use it to place an upper confidence bound on the concentrations in the wall samples using only the currently available sample information. None of the three wall locations (tank heights) has been measured more than once. For radionuclides, only the variation among the concentrations per unit mass (g) of the wall samples, ignoring locations, or the variation among the concentrations of the floor samples are possibilities for establishing an upper confidence bound.

The wall samples and floor samples were examined for comparability by (a) observing whether the wall sample concentrations fell inside the footprints created by prediction intervals for floor sample radionuclide concentrations and (b) whether the variation among the wall samples was approximately the same as the variation among floor samples. Most of the radionuclide concentrations satisfied (a) but the variation among radionuclide concentrations (b) was smaller for the floor samples. Consequently, upper 95\% confidence bounds were established separately for radionuclide concentrations at each of the sampled tank heights using the conservatively estimated variation among the wall samples. A final step to convert concentrations by unit mass ( $g$ ) to concentrations by sq $\mathrm{ft}$ was performed for the Upper Wall Sample and the Lower Wall Sample regions of the tank wall.

The Upper Wall Sample and the Lower Wall Sample were not measured for elemental constituents. Consequently, the only possibility for establishing an upper bound for nonradionuclide concentrations for the Scale Sample was using the concentrations from floor samples. However, most non-radionuclide wall concentrations failed to fall within the footprint generated prediction intervals based on the non-radionuclide concentrations for the floor samples. The report concludes that there is no way to establish upper confidence bounds for elemental constituents attached to the inner liner of Tank 18-F based on currently available data. 
Recommendations for Assessing the Uncertainty in Tank 18-F Wall Samples

SRNL-STI-2010-00525

October 26, 2010

This Page is Intentionally Blank 


\subsection{INTRODUCTION}

The inner vertical wall of the carbon steel lining of Tank 18-F was sampled to support the closure process for the F-Area Tank Farm at the Savannah River Site (SRS). Two wall samples, referred to as the Upper Wall Sample (Sample ID: Tk 18-1) and the Lower Wall Sample (Sample ID: SP4), were each formed from material obtained from two holes drilled into the vertical lining of the tank. The Upper Wall Sample was obtained at a height of $17 \mathrm{ft}$ above the tank floor, and the Lower Wall Sample was obtained at a height of 10 to $12 \mathrm{ft}$ above the tank floor. A Scale Sample (Sample ID: Tk 18-2) was formed from scrapes at 5 locations about 6 to $7 \mathrm{ft}$ above the tank floor. The general term "wall samples" will be used in this report to refer to all three of these samples obtained from the inner tank wall liner.

Since only one wall sample measurement exists at each of the three tank heights, it is impossible to assign an uncertainty to any of the wall sample concentrations without pooling information from across the different wall sample heights or using the information in the floor samples. Therefore, the objective of this report is to compare the concentration results of the three wall samples to each other and then to compare the concentration results of the wall samples to the floor samples. Additionally, determine a method for assessing the uncertainty in the concentration of material still adhering to the tank walls.

Multiple samples have been obtained from the Tank 18-F floor material. The floor sample measurement concentrations were posted in a report by Oji [2010], and a working database of those results was constructed by Harris [2010]. The Tank 18-F wall sample data was reported by Hay and others [2010], and that report contains a detailed description of the sampled material with photographs. The wall concentration data were consolidated with the Harris database for this report.

Radionuclides were measured on all three wall samples, but elemental constituents were only measured on the Scale Sample. Consequently, uncertainty information from sample data is available from the variation among the floor samples and, for radionuclides only, among the wall samples, ignoring their locations (heights in the tank). This report explores whether the concentrations measured on the wall samples are conformable with sample information obtained from the floor material and whether the wall samples themselves yield uncertainty information that can be used to establish upper confidence bounds on wall concentrations. 
Recommendations for Assessing the Uncertainty in Tank 18-F Wall Samples

SRNL-STI-2010-00525

October 26, 2010

This Page is Intentionally Blank 


\subsection{AVAILABLE SAMPLE INFORMATION}

All samples were not measured for every analyte. The sample measurement results from Tables 1 and 2 form the basis for the analyses in Section 3.0. Table 1 consists of only radionuclides that were measured on all three wall samples and the floor samples. Table 2 lists the analytes that have sample measurements to support comparisons of the Scale Sample and floor samples. The table consists of only elemental constituents, since the Upper Wall and Lower Wall samples were not measured for elemental constituents. Table 3 lists analytes that were measured on at least one wall sample, but not on any floor samples. Li has only one measurement on the Scale Sample, so no uncertainty estimate can be established for it. Pu-244 is measured on all three samples from the tank wall, but no uncertainty information is available since all results were below detection. Table 4 lists the analytes that were only measured on floor samples and were contained in the Harris [2010] database; no comparisons with the wall samples are available for the listed analytes. Since this report focuses on the uncertainties for wall samples, the measurement results in Table 4 are unneeded and are only reported here for completeness.

Table 1. Analyte Concentrations Measured on at Least One Sample from Each Location

\begin{tabular}{|l|c|c|c|c|c|}
\hline \multicolumn{7}{|c|}{ Number of Samples Measured for the Indicated Analyte } \\
\hline & & \multicolumn{2}{|c|}{ Wall } & Scale & \\
\hline Analyte & Floor & Lower & Upper & Average & Total \\
\hline Am-241 & 9 & 1 & 1 & 1 & 12 \\
\hline Co-60 & 9 & 1 & 1 & 1 & 12 \\
\hline Cs-137 & 9 & 1 & 1 & 1 & 12 \\
\hline Np-237 & 9 & 1 & 1 & 1 & 12 \\
\hline Pu-238 & 9 & 1 & 1 & 1 & 12 \\
\hline Pu-239 & 9 & 1 & 1 & 1 & 12 \\
\hline Pu-240 & 9 & 1 & 1 & 1 & 12 \\
\hline Pu-241 & 9 & 1 & 1 & 1 & 12 \\
\hline Pu-242 & 3 & 1 & 1 & 1 & 11 \\
\hline Sr-90 & 8 & 1 & 1 & 1 & 12 \\
\hline U-233 & 9 & 1 & 1 & 1 & 12 \\
\hline U-234 & 9 & 1 & 1 & 1 & 12 \\
\hline U-235 & 9 & 1 & 1 & 1 & 12 \\
\hline U-236 & 9 & 1 & 1 & 1 & \\
\hline U-238 & 9 & 1 & 1 & & 1 \\
\hline
\end{tabular}


Table 2. Analytes having Measured Concentrations on the Scale Sample and Floor Samples, but not the Upper or Lower Wall Samples

\begin{tabular}{|c|c|c|c|c|c|c|c|}
\hline \multirow[b]{2}{*}{ Analyte } & \multirow[b]{2}{*}{ Floor } & \multicolumn{2}{|c|}{ Wall } & \multicolumn{3}{|c|}{ Scale } & \multirow[b]{2}{*}{ Total } \\
\hline & & Lower & Upper & Aqua Regia & Peroxide Fusion & Average & \\
\hline $\mathrm{Al}$ & 2 & 0 & 0 & 1 & 1 & 1 & 3 \\
\hline $\mathrm{Ba}$ & 8 & 0 & 0 & 1 & 1 & 1 & 9 \\
\hline $\mathrm{Ca}$ & 2 & 0 & 0 & 1 & 1 & 1 & 3 \\
\hline $\mathrm{Cd}$ & 8 & 0 & 0 & 1 & 1 & 1 & 9 \\
\hline $\mathrm{Cr}$ & 8 & 0 & 0 & 1 & 1 & 1 & 9 \\
\hline $\mathrm{Cu}$ & 8 & 0 & 0 & 1 & 1 & 1 & 9 \\
\hline $\mathrm{Fe}$ & 8 & 0 & 0 & 1 & 1 & 1 & 9 \\
\hline $\mathrm{Mg}$ & 2 & 0 & 0 & 1 & 1 & 1 & 3 \\
\hline Mn & 8 & 0 & 0 & 1 & 1 & 1 & 9 \\
\hline $\mathrm{Ni}$ & 8 & 0 & 0 & 1 & 1 & 1 & 9 \\
\hline $\mathrm{P}$ & 8 & 0 & 0 & 1 & 1 & 1 & 9 \\
\hline $\mathrm{Pb}$ & 8 & 0 & 0 & 1 & 1 & 1 & 9 \\
\hline Si & 2 & 0 & 0 & 1 & 1 & 1 & 3 \\
\hline Sn & 2 & 0 & 0 & 1 & 1 & 1 & 3 \\
\hline $\mathrm{Sr}$ & 2 & 0 & 0 & 1 & 1 & 1 & 3 \\
\hline $\mathrm{Ti}$ & 8 & 0 & 0 & 1 & 1 & 1 & 9 \\
\hline $\mathrm{U}$ & 8 & 0 & 0 & 1 & 1 & 1 & 9 \\
\hline $\mathrm{Zn}$ & 8 & 0 & 0 & 1 & 1 & 1 & 9 \\
\hline
\end{tabular}

Grey shading identifies analytes that also appear in Table 3 because they have wall samples as well as floor and scale samples.

Table 3. Analyte Concentrations Measured on Wall or Scale Samples but not on Floor Samples

\begin{tabular}{lccccccc|}
\hline & \multicolumn{4}{c}{ Wall } & \multicolumn{2}{c|}{ Scale } \\
Analyte & Floor & Lower & Upper & Aqua Regia & Peroxide Fusion & Average & Total \\
$\mathrm{Li}$ & 0 & 0 & 0 & 1 & 1 & 1 & 1 \\
$\mathrm{Pu}-244^{*}$ & 0 & 1 & 1 & 1 & 1 & 1 & 3 \\
\hline * The three measurements of Pu-244 were all below detection limits.
\end{tabular}

Table 4. Analyte Concentrations Measured on Floor Samples but not any Wall or Scale Samples

\begin{tabular}{|l|l|l|l|l|c|l|c|}
\hline \multicolumn{1}{|c|}{ Analyte } & $\begin{array}{l}\text { Number } \\
\text { of Floor } \\
\text { Samples }\end{array}$ & \multicolumn{1}{|c|}{ Analyte } & $\begin{array}{l}\text { Number } \\
\text { of Floor } \\
\text { Samples }\end{array}$ & \multicolumn{1}{|c|}{ Analyte } & $\begin{array}{l}\text { Number } \\
\text { of Floor } \\
\text { Samples }\end{array}$ & Analyte & $\begin{array}{c}\text { Number } \\
\text { of Floor } \\
\text { Samples }\end{array}$ \\
\hline Ag (ICP-MS) & 5 & Cm-244 & 2 & Ni-63 & 8 & Sn-126 & 2 \\
\hline Am-242m & 2 & Co & 2 & NO2-1 & 2 & SO4-2 & 2 \\
\hline Am-243 & 8 & Co3-2 & 2 & NO3-1 & 8 & Tc-99 & 2 \\
\hline Ba-137m & 2 & Cs-135 & 2 & Pb (ICP-MS) & 6 & Th-232 & 2 \\
\hline C-14 & 2 & Eu-154 & 2 & Pu-239/240 & 9 & U-232 & 3 \\
\hline C2O4-2 & 2 & F-1 & 2 & Sb-126 & 2 & Y-90 & 2 \\
\hline Cl-1 & 2 & Hg & 8 & Sb-126m & 2 & & \\
\hline Cm-242 & 2 & Ni-59 & 8 & Sm-151 & 2 & & \\
\hline
\end{tabular}

\footnotetext{
- Aqua Regia and Peroxide Fusion concentrations are not counted in the sample total.
} 


\subsection{RADIONUCLIDE CONCENTRATIONS}

The Upper Wall and Lower Wall Samples were only measured for radionuclides. The results were reported by the surface area of the sample in units of $\mathrm{Ci} / \mathrm{ft}^{2}$ and by the mass of the sample in units of $\mathrm{Ci} / \mathrm{g}$. The Upper Wall Sample was physically larger than the Lower Wall Sample on an area basis and gravimetrically. The surface area of the Upper Wall Sample was reported in Hay [2009] to be $1.36 \cdot 10^{-3} \mathrm{sq} \mathrm{ft}$ or $0.196 \mathrm{sq}$ in, and the Lower Wall Sample was conservatively reported to be $4.37 \cdot 10^{-4} \mathrm{sq} f t$ or $0.0629 \mathrm{sq}$ in. Thus, the Upper Wall Sample was conservatively estimated to have been taken over a surface area 3.1 times that of the Lower Wall Sample. The mass of the drilled material from the Upper Wall Sample was $1.421 \mathrm{~g}$, and the mass of drilled material for the Lower Wall Sample was $0.1967 \mathrm{~g}$. Therefore, the Upper Wall sample had 7.2 times more mass than the Lower Wall Sample.

Table 3-1 from the Hay [2009] report is reproduced in the appendix, and then the original table was augmented by columns for the difference and percent difference between the Upper Wall Sample and Lower Wall Sample concentrations by surface area. Figure 1 displays the concentrations by analyte with the Upper Wall Sample generally having a higher concentration per sq ft than the Lower Wall Sample. In Figure 2, the isotopes of Am, U, Np, and Pu appear to be roughly twice as concentrated in the Upper Wall Sample as in the Lower Wall Sample^. $\mathrm{Co}^{60}$ and $\mathrm{Sr}^{90}$ are also more concentrated by surface area in the Upper Wall Sample than in the Lower Wall Sample, but only by $20 \%$ and $40 \%$, respectively. Only $\mathrm{Cs}^{137}$ is less concentrated by surface area in the Upper Wall Sample than in the Lower Wall Sample. The inconsistency displayed by $\mathrm{Cs}^{137}$ may suggest that the source of the radioactive material at the $17 \mathrm{ft}$ elevation may have differed from the source of the material at the 10 to $12 \mathrm{ft}$ elevation in the tank.

Table 3-2 from the Hay [2009] report is also reproduced in the appendix, and then augmented by columns for the difference and percent difference between the Upper Wall Sample and Lower Wall Sample concentrations by mass (g) of the sampled material. The concentrations by mass (g) are plotted in Figure 3 by individual radionuclides. $\mathrm{Am}^{241}$, $\mathrm{Np}^{237}$, and all of the $\mathrm{U}$ isotopes and most of the $\mathrm{Pu}$ isotopes are found to the same or higher concentrations in the Upper Wall Sample than observed in the Lower Wall Sample. The concentration of $\mathrm{Pu}^{238}$ is higher than the concentration of any other $\mathrm{Pu}$ isotope in both the Upper Wall and the Lower Wall Samples. $\mathrm{Cs}^{137}, \mathrm{Sr}^{90}$, and $\mathrm{Co}^{60}$ are less concentrated by mass in the Upper Wall Sample than the Lower Wall Sample. The percent differences between the Upper Wall Sample and Lower Wall Sample concentrations by g are plotted in Figure 4. The results appear to be shifted closer to an average zero percent difference than the results in Figure 2 that were based on concentrations by area. Thus it appears that the area for the Lower Wall Sample may have been overestimated relative to the Upper Wall Sample, since the drilled areas were calculated conservatively, whereas, the mass was an actual measurement.

^ $\mathrm{Pu}^{244}$ was less than the analytical reporting limit for the Upper Wall and the Lower Wall sample. 


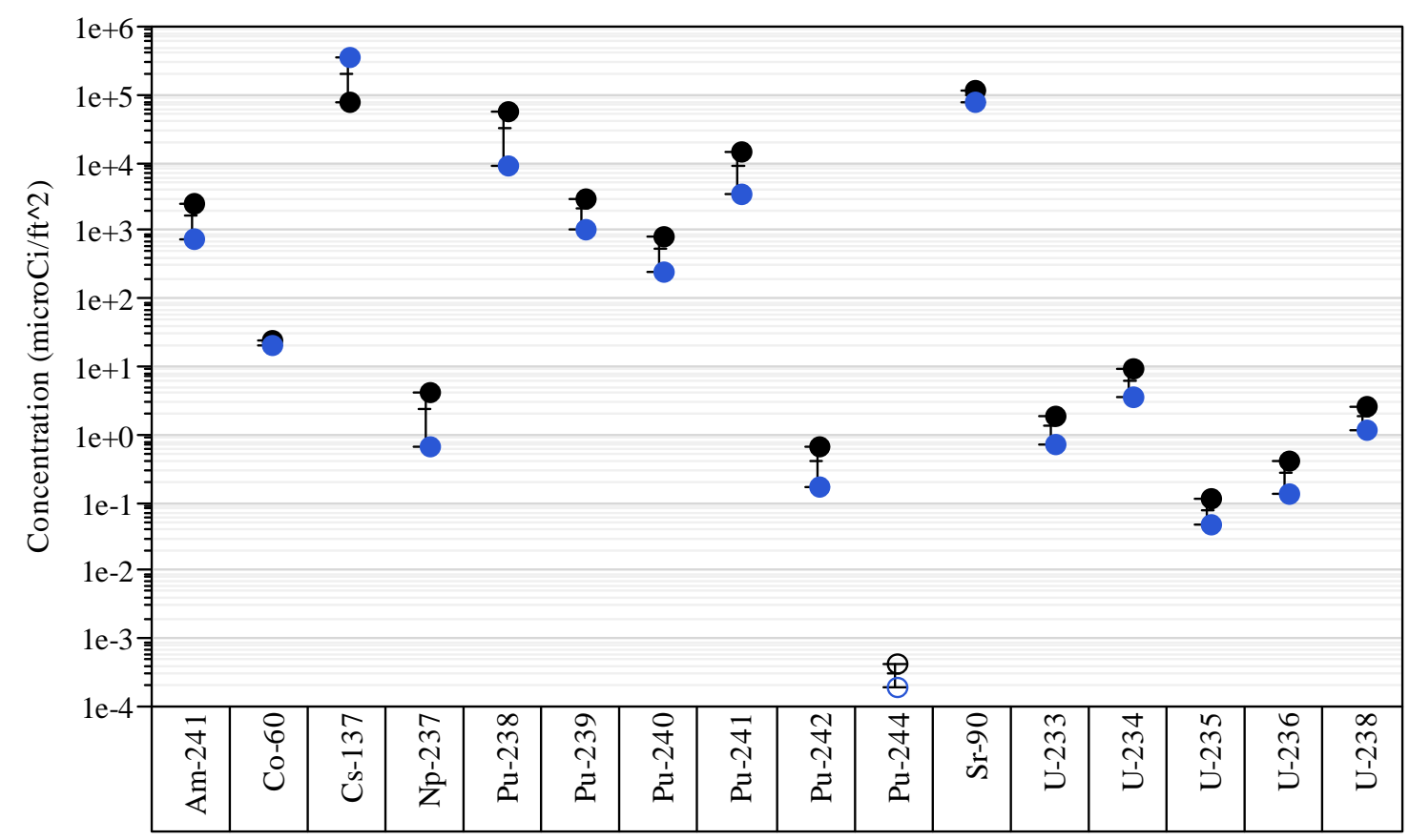

Figure 1. Plot of the Radionuclide Concentrations per Unit Area $\left(\mu \mathrm{Ci} / \mathrm{ft}^{2}\right)$ for the Upper Wall and the Lower Wall Samples

(Legend: Black-Upper Wall sample; Blue-Lower Wall sample;

Closed Circle-Measured value and Open Circle-Analytical reporting limit for a censored measurement)

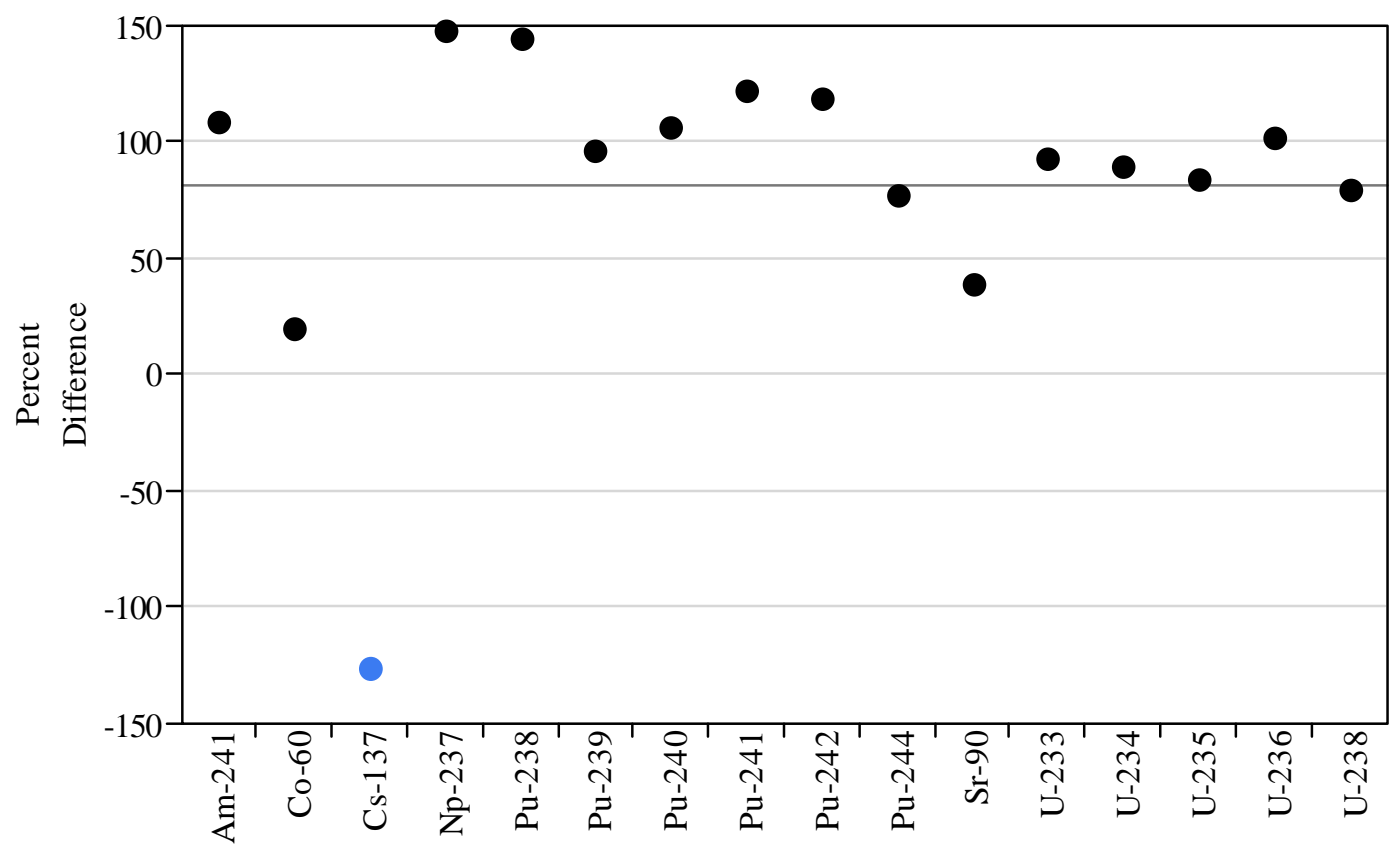

Analyte

Figure 2. Plot of the Percent Differences between the Radionuclide Concentrations per Unit Area $\left(\mu \mathrm{Ci} / \mathrm{ft}^{2}\right)$ for the Upper Wall and the Lower Wall Sample

(Legend: Black-Upper Wall sample concentration larger; Blue-Lower Wall sample concentration larger) 


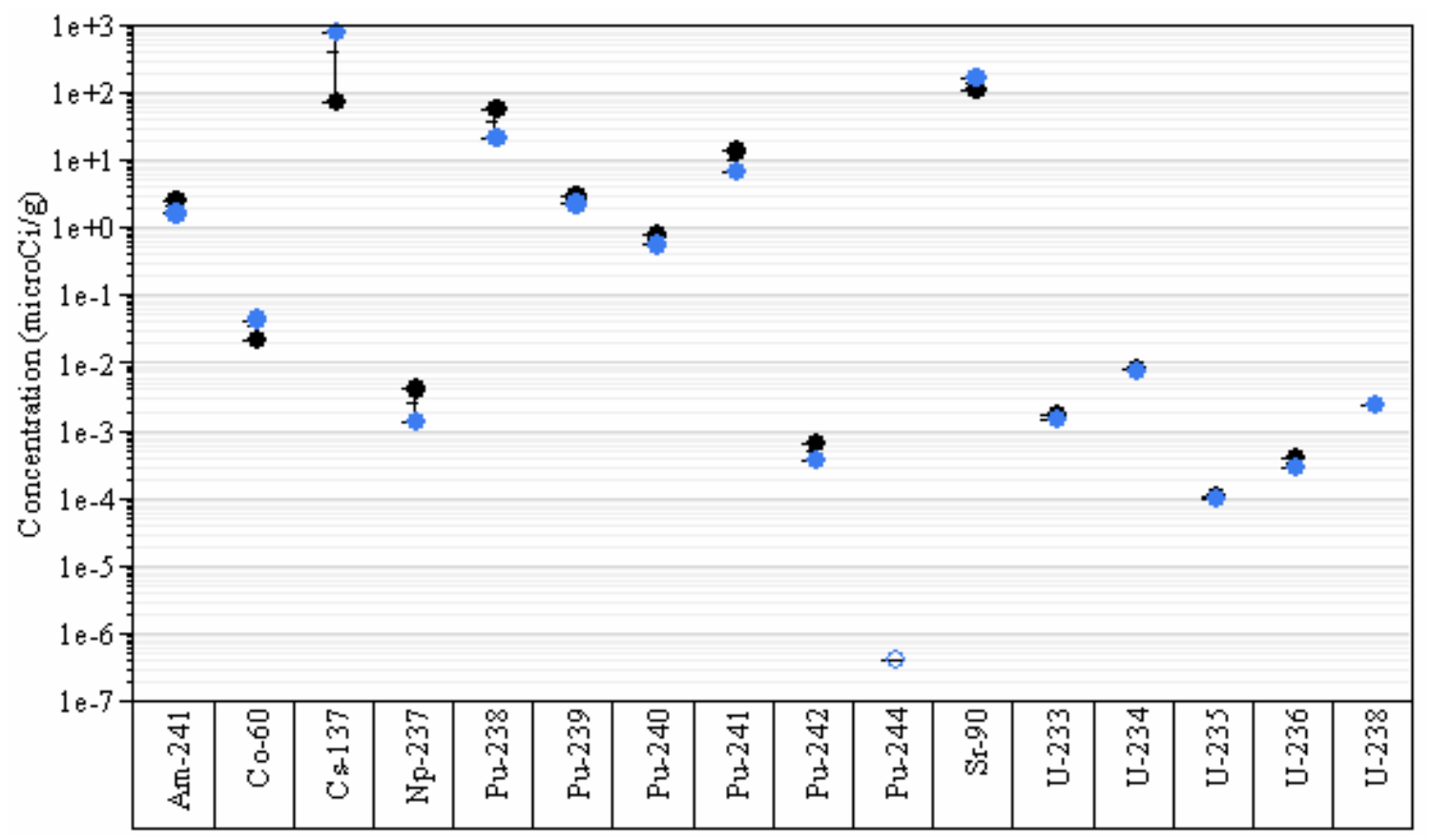

Figure 3. Plot of the Analyte Radionuclide Concentrations per Gram of Sampled Material $(\mu \mathrm{Ci} / \mathrm{g})$ for the Upper Wall and the Lower Wall Samples

Legend: Black-Upper Wall Sample and Blue-Lower Wall Sample Closed Circle-Concentration Measurement and

Open Circle-Analytical Reporting Limit for a censored concentration measurement

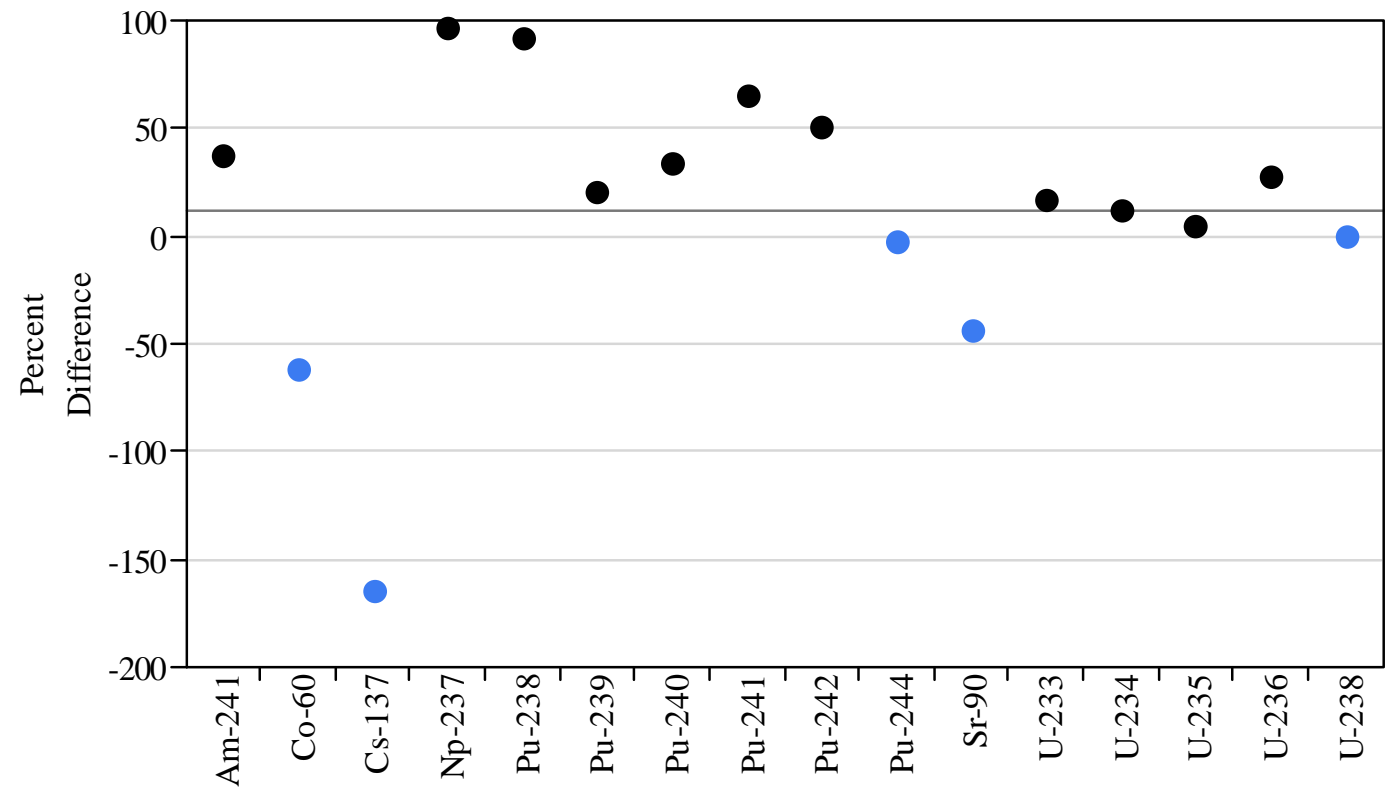

Figure 4. Plot of Percent Differences between the Radionuclide Concentrations per Gram of Sampled Material $(\mu \mathrm{Ci} / \mathrm{g})$ for the Upper Wall and the Lower Wall Samples Legend: Black-Upper Wall Sample concentration is greater than the Lower Wall Sample concentration 
Blue-Upper Wall Sample concentration is less than or equal to the Lower Wall Sample concentration

In the following analysis, each wall sample will be compared to the floor sample distribution. A graphical test will be conducted in order to verify that each measured analyte of a wall sample conforms to (lies inside the limits of) a prediction interval established for floor samples. The concentrations by mass (g) of radionuclides are listed in Table 5 for the wall samples. The mean and standard deviation for the floor samples were computed, and each of the wall and scale samples was "studentized", thereby referencing them to the floor sample distribution by the following formula.

$$
Z_{\text {analyte }}=\frac{\text { Conc }_{\text {Wall Sample }}-\overline{\text { Conc }}_{\text {floor }}}{S D_{\text {floor }}},
$$

where Conc $_{\text {Wall sample }}$ refers to a concentration by mass (g) of a wall sample measurement from Table 5. If the analyte measured on the tank wall has the same distribution as the floor samples, then the mean and standard deviation of $z_{\text {analyte }}$ should be 0 and 1 , respectively, and $z_{\text {analyte }}$ should plot between the outer control limits. These studentized concentrations were plotted by analyte in Figure 5. The Upper Wall Sample and Lower Wall Sample concentrations are plotted with a black circle and a blue circle, respectively. The Scale Sample concentrations are plotted with a green circle. Prediction limits based on the assumption of normally distributed sample concentrations were plotted for 95\% and 99\% confidence on the graph for one and three "new" samples using normal prediction limits given in Hahn and Meeker [1991]. "New" refers to the wall samples in this context, and the wall samples are considered new because their sample information was not used to establish the floor prediction intervals. Thus, to compare the fit of wall samples as a collection of three new samples from the tank wall to the distribution of the floor samples, the control lines for three new samples should be used. Using 99\% confidence, only points between the upper and lower solid red lines are predicted by the floor sample distribution.

Most of the radionuclides appear to be predicted by the floor sample distribution because they fall between the solid red lines. The exceptions are all three tank wall samples for $\mathrm{Pu}^{238}$ and $\mathrm{Sr}^{90}$ and just the Scale Sample (6 to $7 \mathrm{ft}$ above the tank floor) for $\mathrm{Co}^{60}$ and $\mathrm{Pu}^{242}$.

Besides the preceding analysis for individual wall samples, the variation among the wall samples must be compared to the variation found among the floor samples. Table 6 contains the mean and standard deviation for the three wall sample concentrations. Ignoring the heights of the samples, the three wall samples are treated like they were obtained at random locations. Similar statistics for the floor samples are given in Table 7. An F-test for the ratio of the wall variance to the floor variance was performed based on the following test statistic. 


$$
F=\left(\frac{\operatorname{Max}\left\{S D_{\text {Wall Samples }}, S D_{\text {Floor Samples }}\right\}}{\operatorname{Min}\left\{S D_{\text {Wall Samples }}, S D_{\text {Floor Samples }}\right\}}\right)^{2},
$$

Table 5. Radionuclide Concentrations $(\mu \mathrm{Ci} / \mathrm{g})$ by Wall Sample Location

\begin{tabular}{|c|c|c|c|}
\hline Radionuclide & Scale Sample & Lower Wall Sample & Upper Wall Sample \\
\hline $\mathrm{Am}^{241}$ & 7.7 & 1.67 & 2.43 \\
\hline $\mathrm{Co}^{60}$ & 0.112 & 0.0449 & 0.0236 \\
\hline $\mathrm{Cs}^{137}$ & 87.2 & 758 & 73.2 \\
\hline $\mathrm{Np}^{237}$ & 0.00409 & 0.00142 & 0.00403 \\
\hline $\mathrm{Pu}^{238}$ & 15.1 & 20.3 & 54.5 \\
\hline $\mathrm{Pu}^{239}$ & 9.58 & 2.36 & 2.9 \\
\hline $\mathrm{Pu}^{240}$ & 2.16 & 0.551 & 0.774 \\
\hline $\mathrm{Pu}^{241}$ & 17.4 & 6.87 & 13.5 \\
\hline $\mathrm{Pu}^{242}$ & 0.0018 & 0.000384 & 0.000646 \\
\hline $\mathrm{Sr}^{90}$ & 270 & 170 & 109 \\
\hline $\mathrm{U}^{233}$ & 0.00203 & 0.00157 & 0.00185 \\
\hline $\mathrm{U}^{234}$ & 0.00814 & 0.00778 & 0.00874 \\
\hline $\mathrm{U}^{235}$ & 0.000279 & 0.000101 & 0.000106 \\
\hline $\mathrm{U}^{236}$ & 0.000332 & 0.000303 & 0.000399 \\
\hline $\mathrm{U}^{233}$ & 0.00684 & 0.00247 & 0.00246 \\
\hline * & $\mathrm{A}$ measurement is studentized by first subtracting off its mean, then dividing the resulting difference by the standard deviation. \\
\hline
\end{tabular}

$\mathrm{P}$-values and the test results by radionuclide are listed in the Table 6. Except for $\mathrm{Cs}^{137}$, $\mathrm{Np}^{237}$, and most $\mathrm{U}$ isotopes, the ratios are statistically significant. Therefore, there appears to be more variability among the wall samples than the floor samples for most analytes. So while most wall radionuclide concentrations fall within the footprint of the floor concentrations, there appears to be more variability among most of the wall sample results than the floor sample results. The standard deviation of the 3 wall samples will tend to be conservatively large due to actual differences among the locations. There does not appear to be sufficient evidence to use the floor sample variation to characterize the uncertainty in the wall samples, since there are no replicate sample measurements at the same height in the tank to compare the floor samples with, and the variation among samples at different heights exceeds the variation seen in the floor samples for most radionuclides. The floor concentration results will no longer be considered to support an uncertainty determination for the wall samples.

In order to establish an upper confidence bound for the concentration of tank wall radionuclides without additional tank wall sampling, the variation among the wall samples will be used to establish an estimate of the wall sample concentration standard deviation. This estimate is considered to be conservative, since the vertical axis probably contains the greater systematic differences due to process conditions than would be expected at different locations at the same height above the tank floor. 


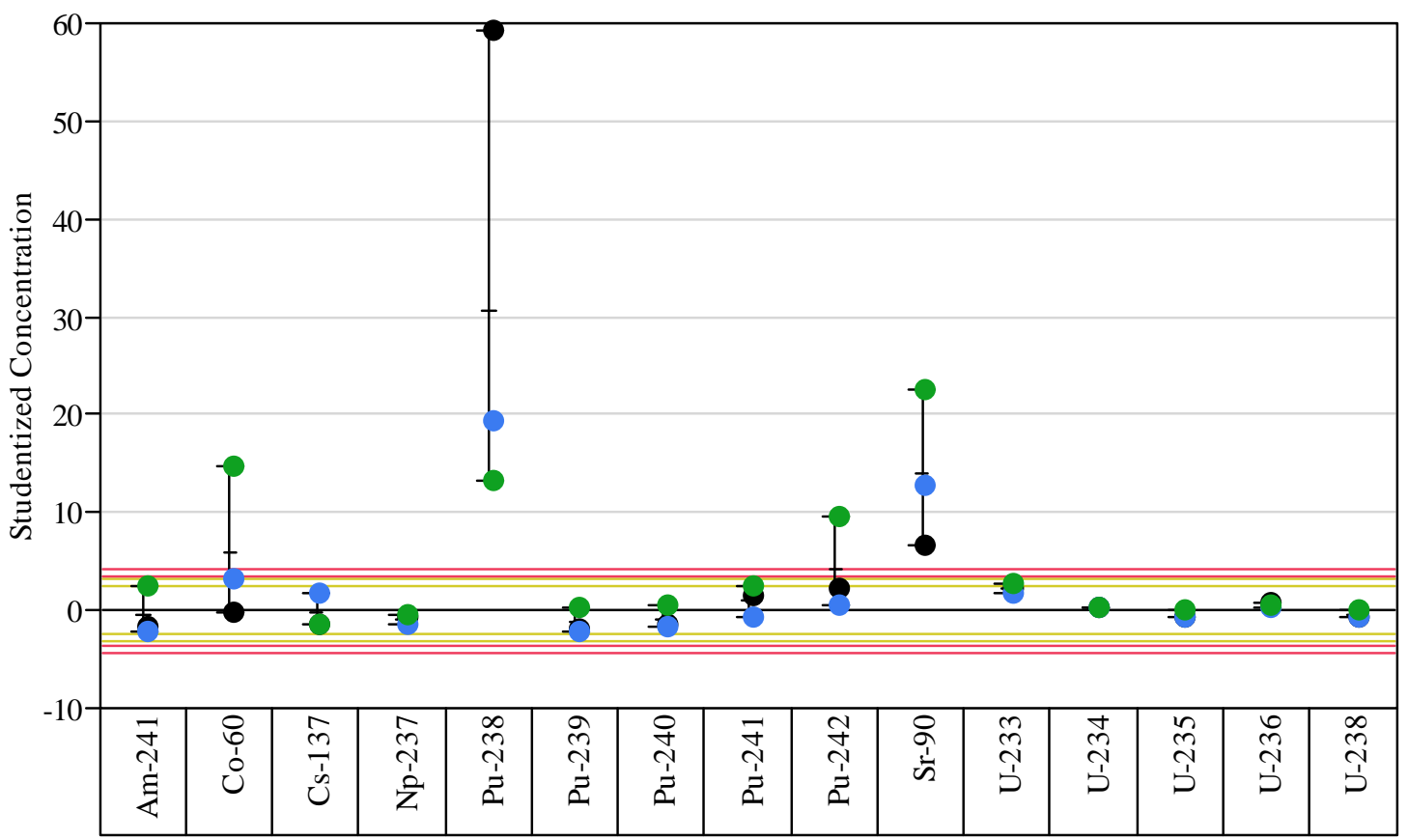

(a) Plot of the Tank 18-1 Concentrations

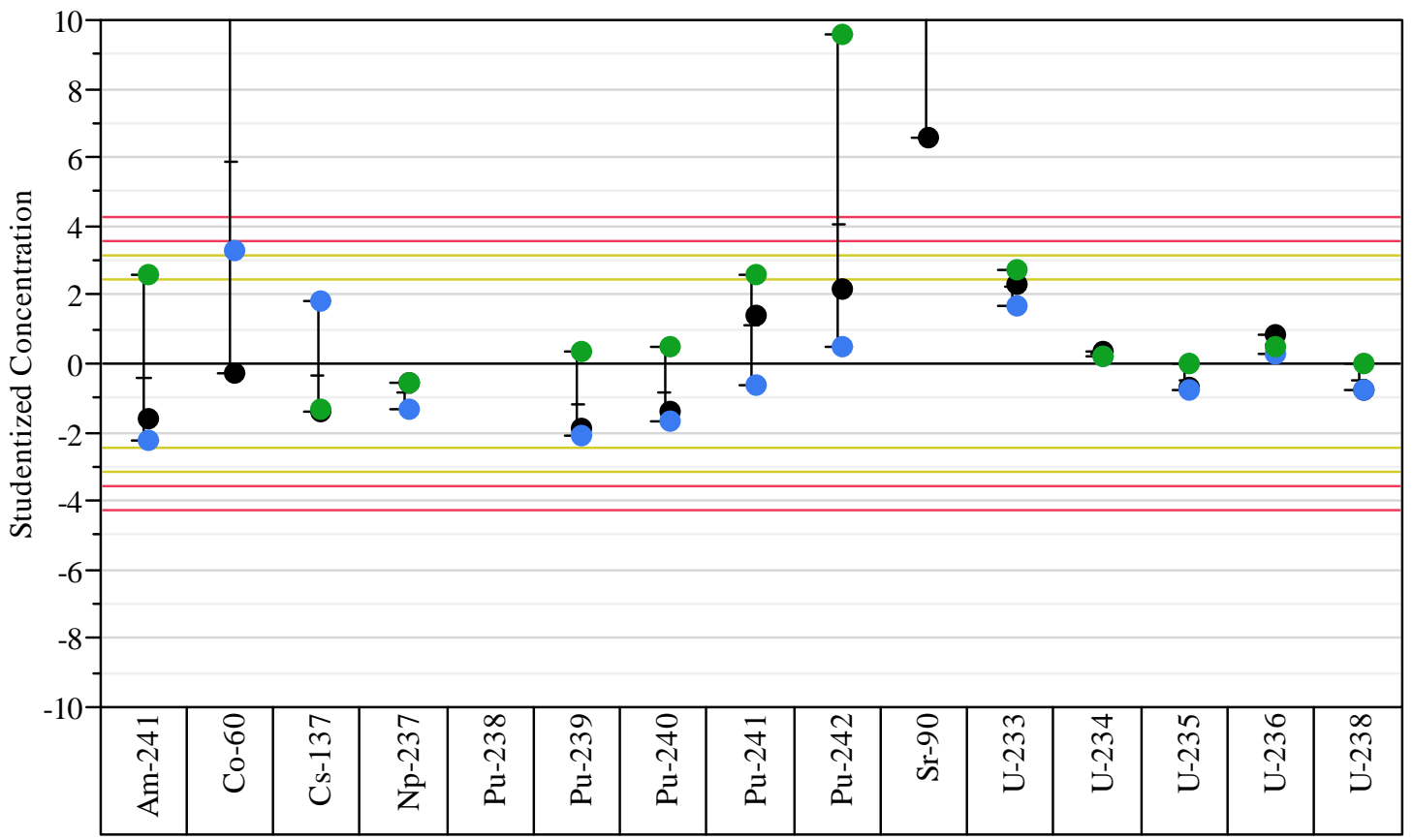

(b) Restricted Range for the Plot of the Tank 18-1 Concentrations

Figure 5. Studentized Radionuclide Concentrations per Gram of Sampled Material $(\mu \mathrm{Ci} / \mathrm{g})$ for the Upper Wall, the Lower Wall, and the Scale Samples

Legend: Black-Upper Wall Sample, Blue-Lower Wall Sample, and Green-Scale Sample Yellow 95\% Confidence 2-sided Normal Prediction Limits: Dashed:1 new sample and Solid:3 new samples Red 99\% Confidence 2-sided Normal Prediction Limits: Dashed:1 new sample and Solid:3 new samples 
Table 6 also displays 95\% upper confidence bands for the radionuclides based on the treating the wall samples as a random sample of size 3 . These are calculated from the formula:

$$
\text { UCBand }_{95 \%}=\frac{t_{0.95,2 d f} \cdot \frac{\text { StdDev }_{\text {Wallsamples }}}{\sqrt{1}}}{\text { Mean }_{\text {Wallsamples }}}
$$

Formula (3) is the width of the confidence band (between the mean and the upper confidence bound) relative to the mean concentration. A value of 0.5 , for example, can be interpreted as the UCL exceeds the mean by $50 \%$. Note that the sample size divisor in the square root is one, because there is only one wall sample in each location (tank height). This band is used in conjunction with the wall and scale sample concentrations to obtain an upper bound as follows.

$$
U C L_{95 \%}=\text { Conc }_{\text {Wall Sample }} \cdot\left(1+\text { UCBand }_{95 \%}\right)
$$

This 95\% upper confidence bound is on the concentration for the region of the tank wall at the indicated wall height relative. The results are given in Table 8. Note that this concentration is relative to mass (g). The upper confidence bounds for the concentration on a square foot basis can be obtained by multiplying the $U C L_{95 \%}$ for a particular sample by the grams per square foot for that sample. The grams per square foot for the Upper Wall Sample are $1.421 \mathrm{~g} / 0.00136 \mathrm{sq} \mathrm{ft}$. The grams per square foot for the Lower Wall sample are $0.1967 \mathrm{~g} / 0.000437 \mathrm{sq} \mathrm{ft}$. The mass of the Scale Sample is $1.1846 \mathrm{~g}$ with no square footage given in the Hays and others [2009] report. The 95\% upper confidence bounds on the concentrations per sq ft for the tank regions of the Upper Wall Sample and the Lower Wall Sample are given in the last two columns of Table 8. 
Table 6. 95\% Upper Confidence Bands (UCL-Mean) for Radionuclides based solely on the Wall and Scale Sample Results

\begin{tabular}{|c|c|c|c|c|c|c|}
\hline Radionuclide & $\begin{array}{c}\text { Wall* Mean } \\
(\mu \mathrm{Ci} / \mathrm{g})\end{array}$ & $\begin{array}{l}\text { Wall* Std Dev } \\
\quad(\mu \mathrm{Ci} / \mathrm{g})\end{array}$ & $\begin{array}{l}\text { P-value for F-ratio of } \\
\text { Wall to Floor Variances }\end{array}$ & $\begin{array}{c}\text { 95-th t } \\
\text { Quantile w/2df }\end{array}$ & $\begin{array}{c}\text { t*Std Err of Mean } \\
(\mu \mathrm{Ci} / \mathrm{g})\end{array}$ & $\begin{array}{l}\text { Ratio of } t^{*} \text { Std } \\
\text { Error to Mean }\end{array}$ \\
\hline Am-241 & 3.93333333 & 3.2840879 & 0.0001 (signif @0.05) & 2.91998 & 9.58948931 & 2.4380 \\
\hline Сo-60 & 0.06016667 & 0.04613506 & 0.0000 (signif @0.05) & 2.91998 & 0.13471371 & 2.2390 \\
\hline Cs-137 & 306.133333 & 391.390615 & 0.8458 & 2.91998 & $1,142.85495$ & 3.7332 \\
\hline Np-237 & 0.00318 & 0.0015245 & 0.2846 & 2.91998 & 0.00445152 & 1.3998 \\
\hline $\mathrm{Pu}-238$ & 29.9666667 & 21.4049838 & $<0.0001$ (signif @0.05) & 2.91998 & 62.502244 & 2.0857 \\
\hline Pu-239 & 4.946666667 & 4.02165803 & 0.0067 (signif @0.05) & 2.91998 & 11.7431835 & 2.3740 \\
\hline $\mathrm{Pu}-240$ & 1.16166667 & 0.87174213 & 0.0118 (signif @0.05) & 2.91998 & 2.54547445 & 2.1912 \\
\hline $\mathrm{Pu}-241$ & 12.59 & 5.32365476 & 0.0003 (signif @0.05) & 2.91998 & 15.5449951 & 1.2347 \\
\hline Pu-242 & 0.00094333 & 0.00075337 & 0.0074 (signif @0.05) & 2.91998 & 0.00219983 & 2.3320 \\
\hline Sr-90 & 183 & 81.2834547 & $<0.0001$ (signif @0.05) & 2.91998 & 237.346516 & 1.2970 \\
\hline U-233 & 0.00181667 & 0.0002318 & 0.0008 (signif @0.05) & 2.91998 & 0.00067685 & 0.3726 \\
\hline U-234 & 0.00822 & 0.00048497 & 0.2326 & 2.91998 & 0.00141611 & 0.1723 \\
\hline U-235 & 0.000162 & 0.00010136 & 0.2878 & 2.91998 & 0.00029597 & 1.8270 \\
\hline U-236 & 0.00034467 & $4.92375 e-5$ & 0.0874 & 2.91998 & 0.00014377 & 0.4171 \\
\hline $\mathrm{U}-238$ & 0.00392333 & 0.00252591 & 0.2948 & 2.91998 & 0.00737562 & 1.8799 \\
\hline
\end{tabular}

* The wall mean and standard deviation are based on the three wall sample results: the Upper Wall Sample, the Lower Wall Sample, and the Scale Sample; that is, 2 degrees of freedom. "Signif" designates that an F-test for the ratio of the wall variance (from Table 6) to the floor variance (from Table 7) resulted in a significant ratio at $\alpha=0.05$. The standard error for the mean is based on $n=1$ sample from a wall area.

Table 7. 95\% Upper Confidence Bands (UCL-Mean) of the Mean Analyte Concentration per $\mathrm{g}$ by Location

\begin{tabular}{|c|c|c|c|c|c|c|}
\hline Radionuclide & $\begin{array}{c}\text { Floor Mean } \\
(\mu \mathrm{Ci} / \mathrm{g})\end{array}$ & $\begin{array}{l}\text { Floor Std Dev } \\
\qquad(\mu \mathrm{Ci} / \mathrm{g})\end{array}$ & $\begin{array}{l}\text { Std Err of Floor } \\
\text { Mean }(\mu \mathrm{Ci} / \mathrm{g})\end{array}$ & $\begin{array}{c}\text { 95-th t } \\
\text { Quantile w/vdf }\end{array}$ & $\begin{array}{l}t^{*} \text { Std Err of Mean } \\
(\mu \mathrm{Ci} / \mathrm{g})\end{array}$ & $\begin{array}{l}\text { Ratio of } t^{*} \text { Std } \\
\text { Error to Mean }\end{array}$ \\
\hline Am-241 & 4.4842957 & 1.2519785 & 0.4173262 & 2.30601 & 3.6557592 & 0.8152 \\
\hline Co-60 & 0.0252945 & 0.0059197 & 0.0019732 & 2.91999 & 0.01728544 & 0.6834 \\
\hline Cs-137 & 374.47778 & 210.87509 & 70.291697 & 2.91999 & 615.752228 & 1.6443 \\
\hline Np-237 & 0.0060044 & 0.003366 & 0.001122 & 2.91999 & 0.00982873 & 1.6369 \\
\hline $\mathrm{Pu}-238$ & 3.6978889 & 0.8575235 & 0.2858412 & 2.91999 & 2.50395634 & 0.6771 \\
\hline Pu-239 & 8.6252222 & 3.0293139 & 1.0097713 & 2.91999 & 8.84555302 & 1.0255 \\
\hline $\mathrm{Pu}-240$ & 1.812037 & 0.7570948 & 0.2523649 & 2.91999 & 2.21070584 & 1.2200 \\
\hline $\mathrm{Pu}-241$ & 8.8881111 & 3.326199 & 1.108733 & 2.91999 & 9.71245303 & 1.0927 \\
\hline $\mathrm{Pu}-242$ & 0.0003102 & 0.0001553 & 8.969E-05 & 2.91999 & 0.00045359 & 1.4622 \\
\hline Sr-90 & 42.99125 & 10.025099 & 3.5444078 & 2.91999 & 29.2731448 & 0.6809 \\
\hline U-233 & 0.000796 & 0.000457 & 0.0001524 & 2.91999 & 0.00133473 & 1.6764 \\
\hline U-234 & 0.006691 & 0.006136 & 0.0020454 & 2.91999 & 0.01791782 & 2.6780 \\
\hline U-235 & 0.000273 & 0.000231 & 7.694E-05 & 2.91999 & 0.00067396 & 2.4722 \\
\hline U-236 & 0.000249 & 0.000181 & $6.04 \mathrm{E}-05$ & 2.91999 & 0.00052907 & 2.1220 \\
\hline U-238 & 0.006913 & 0.005723 & 0.0019077 & 2.91999 & 0.01671175 & 2.4175 \\
\hline
\end{tabular}

The standard error for the mean is based on $\mathrm{n}=1$ sample from a wall area. Note that the $95 \%$ upper confidence bounds in this table are based on the variation observed in floor sample radionuclide concentrations. These have not been shown to be compatible with the wall sample concentrations, so only the 95\% upper confidence bounds from Table 6 are to be used. 
Recommendations for Assessing the Uncertainty in Tank 18-F Wall Samples

SRNL-STI-2010-00525

October 26, 2010

Table 8. 95\% Upper Confidence Bounds for Concentration per unit mass (g) at Individual Wall Sample Locations (Tank Heights)

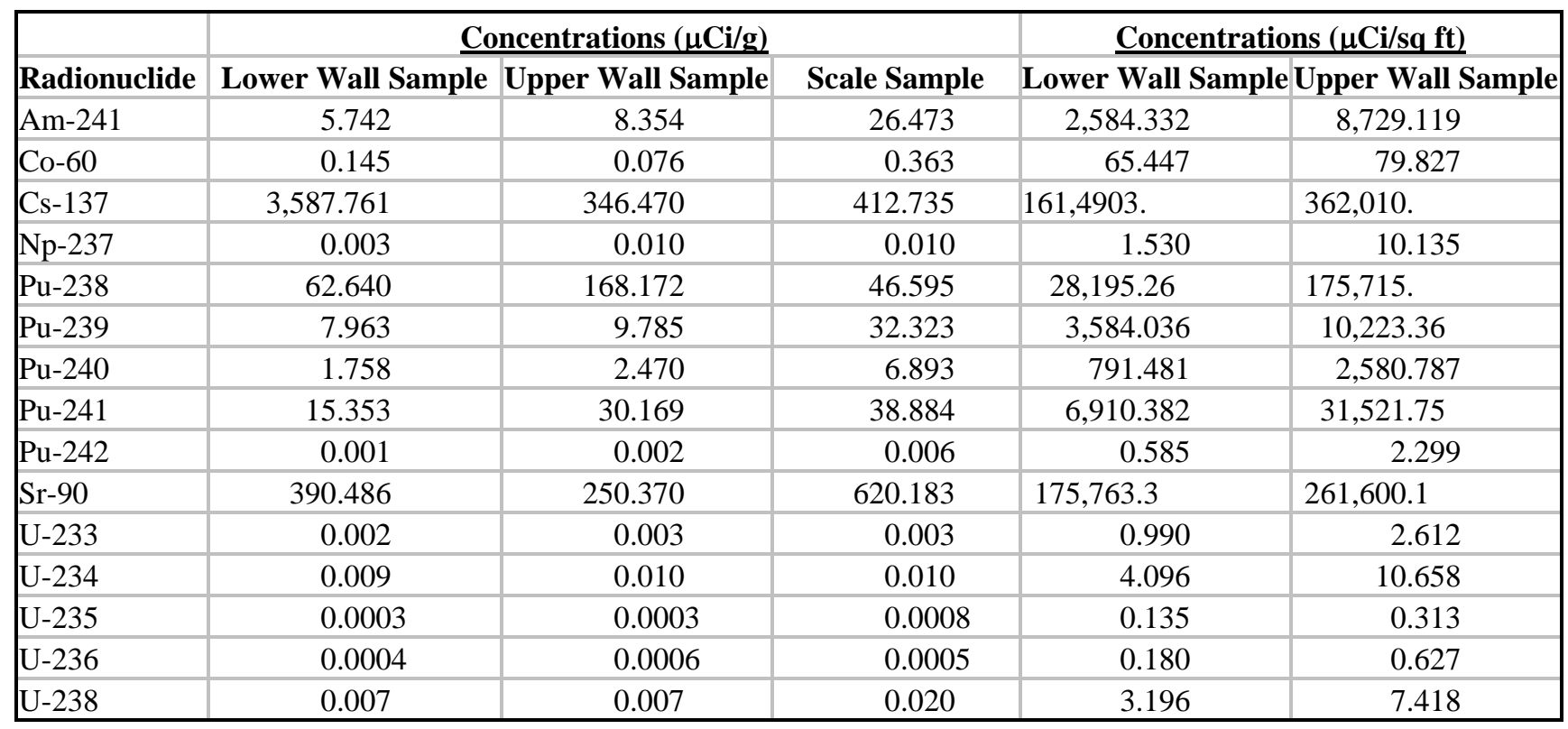

Upper Wall Sample: 1,044.853 g/sq ft and Lower Wall Sample: $450.114 \mathrm{~g} / \mathrm{sq} \mathrm{ft}$ 
Recommendations for Assessing the Uncertainty in Tank 18-F Wall Samples

SRNL-STI-2010-00525

October 26, 2010

This Page is Intentionally Blank 


\subsection{ELEMENTAL CONCENTRATIONS}

Elemental constituents have only been measured on the Scale Sample (in addition to the floor measurements). Therefore, the approach taken to establish an upper confidence bound for radionuclides cannot be followed for the elemental constituents because there is no measure of the standard deviation available from a single wall sample.

Figure 6 plots the studentized values for the non-radionuclide wall sample concentrations by mass (g), referenced to the floor sample distribution using Formula (1). Unlike the radionuclides, many of the elemental constituents do not appear to be adequately predicted by the floor samples. Thus the floor sample data should not be used for establishing confidence bounds for elemental constituents. There does not appear to be a basis for establishing upper confidence bounds on the elemental constituents on the tank wall without further sampling. 


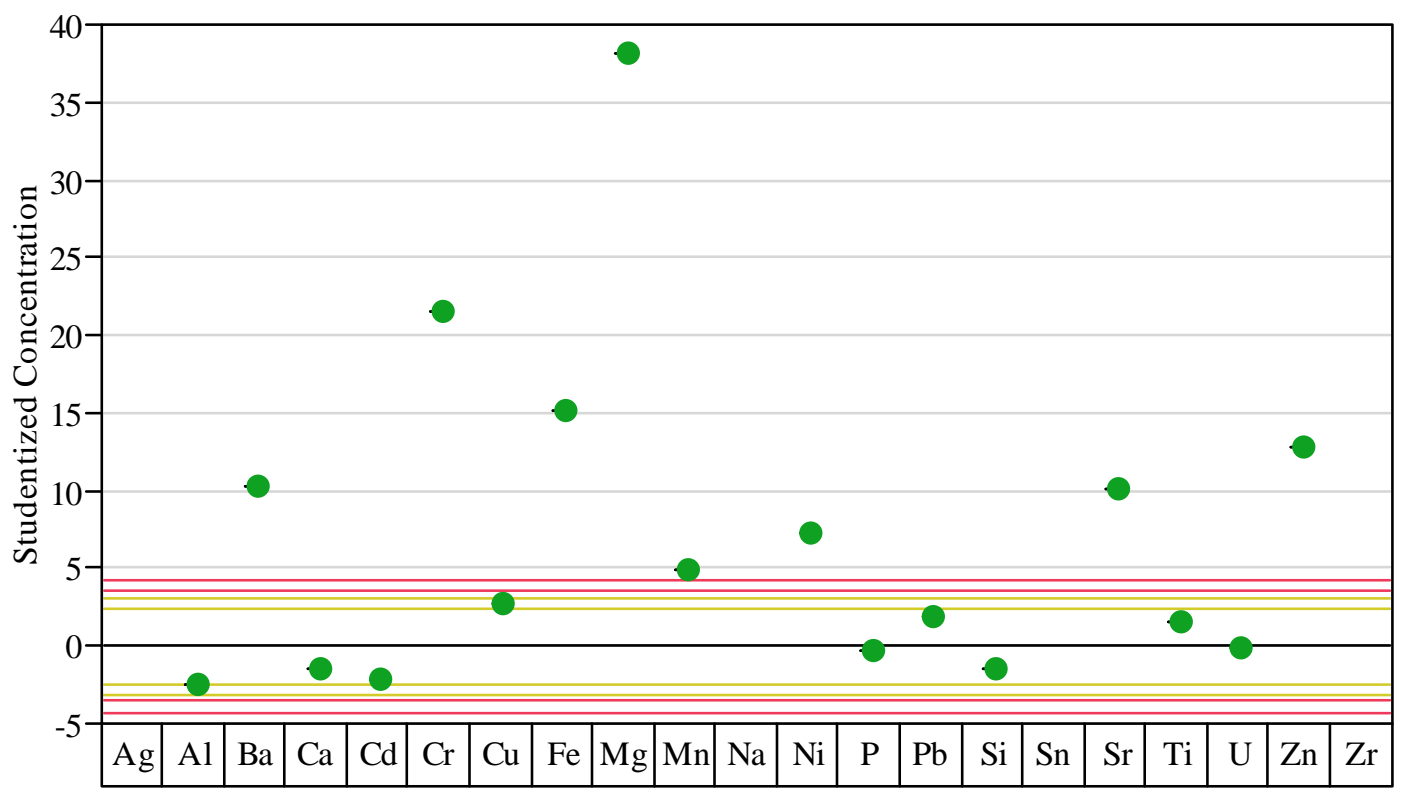

(a) Plot of the Studentized Concentrations

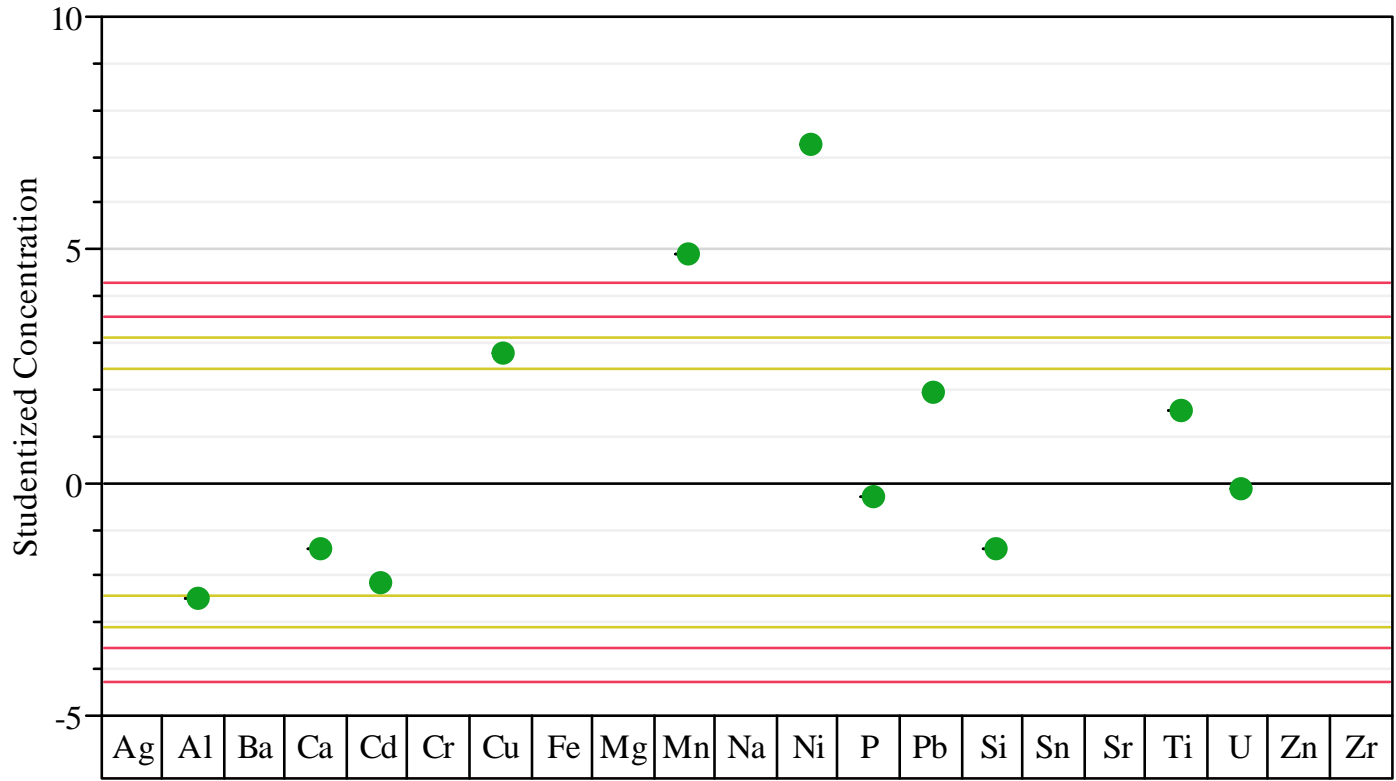

(b) Plot of the Studentized Concentrations in the Range \pm 10 Sigma

Figure 6. Studentized Non-radionuclide Concentrations per Gram of Sampled Material for the Upper Wall, the Lower Wall, and the Scale Samples $(\mu \mathrm{g} / \mathrm{g})$

Legend: Black-Upper Wall Sample, Blue-Lower Wall Sample, and Green-Scale Sample Yellow 95\% Confidence 2-sided Normal Prediction Limits: Dashed:1 new sample and Solid:3 new samples Red 99\% Confidence 2-sided Normal Prediction Limits: Dashed:1 new sample and Solid:3 new samples 


\subsection{RESULTS AND CONCLUSIONS}

The following strategy was used to establish an upper confidence limit on radionuclide concentrations. The wall samples and floor samples were examined for comparability by (a) observing whether the wall sample concentrations fell inside the footprints created by prediction intervals for floor sample radionuclide concentrations and (b) whether the variation among the wall samples was approximately the same as the variation among floor samples. Most of the radionuclide concentrations satisfied (a) but the variation among radionuclide concentrations (b) was smaller for the floor samples. Consequently, upper 95\% confidence bounds were established separately for radionuclide concentrations at each of the sampled tank heights using the conservatively estimated variation among the wall samples. The upper confidence bound for the concentration per $\mathrm{g}$ of material is given for the radionuclides in Table 8 on page 12. A final step to convert concentrations by unit mass (g) to concentrations by sq $\mathrm{ft}$ was performed for the Upper Wall Sample and the Lower Wall Sample regions of the tank wall.

Implementation of this strategy resulted in a standard deviation computed from just the wall sample concentrations per unit mass (g). The upper confidence bound for the concentration per $\mathrm{g}$ of material is given in Table 8 on page 12. The upper confidence bound per $g$ of material was then converted to an upper confidence bound per unit area using the grams per square foot observed for the Upper Wall Sample and the Lower Wall Sample. The results for the upper confidence intervals for concentration per sq $\mathrm{ft}$ are also given in Table 8. 
Recommendations for Assessing the Uncertainty in Tank 18-F Wall Samples

SRNL-STI-2010-00525

October 26, 2010

This Page is Intentionally Blank 


\subsection{REFERENCES}

[1991] Hahn, G.J. and Meeker, W.Q. Statistical Intervals: A Guide for Practitioners, John Wiley \& sons, Inc.

[2009] Hay, M.S; Click, D.R.; Diprete, D.P.; and Diprete, C.C. "Characterization of Tank 18 Wall and Scale Samples," Savannah River National Laboratory Technical Report SRNL-STI-2009-00802, Rev. 0 (March)

[2010] Harris, S.P. "EPS Tank 18 z.JMP," Applied Computational Engineering and Statistics Section, Savannah River National Laboratory (database of Tank 18 closure sample results in the JMP software data file format).

[2010] Oji, L. (Tank 18 data transmission document). 
Recommendations for Assessing the Uncertainty in Tank 18-F Wall Samples

SRNL-STI-2010-00525

October 26, 2010

This Page is Intentionally Blank 


\section{APPENDIX}

Table 3-1. Tank 18F Wall Sample Concentration Results per Unit Area

\begin{tabular}{|l|l|c|c|c|c|c|}
\hline Isotope & $\begin{array}{c}\text { Analytical } \\
\text { Method }\end{array}$ & $\begin{array}{c}\text { Wall Sample Target } \\
\text { Detection Limit Ci/ft }\end{array}$ & $\begin{array}{c}\text { Tk 18-1 (Upper } \\
\text { Wall) Ci/ft }\end{array}$ & $\begin{array}{c}\text { SP4 (Lower } \\
\text { Wall) Ci/ft }\end{array}$ & $\begin{array}{c}\text { Difference } \\
\text { Ci/ft }^{2}\end{array}$ & $\begin{array}{c}\text { Percent } \\
\text { Difference }\end{array}$ \\
\hline U-233 & S/ICP-MS & $1.98 \mathrm{E}-05$ & $1.93 \mathrm{E}-06$ & $7.08 \mathrm{E}-07$ & $1.22 \mathrm{E}-06$ & $92.6 \%$ \\
\hline $\mathrm{U}-234$ & S/ICP-MS & $1.27 \mathrm{E}-05$ & $9.13 \mathrm{E}-06$ & $3.50 \mathrm{E}-06$ & $5.63 \mathrm{E}-06$ & $89.2 \%$ \\
\hline U-235 & S/ICP-MS & $1.16 \mathrm{E}-08$ & $1.11 \mathrm{E}-07$ & $4.55 \mathrm{E}-08$ & $6.55 \mathrm{E}-08$ & $83.7 \%$ \\
\hline $\mathrm{U}-236$ & S/ICP-MS & $1.32 \mathrm{E}-07$ & $4.17 \mathrm{E}-07$ & $1.36 \mathrm{E}-07$ & $2.81 \mathrm{E}-07$ & $101.6 \%$ \\
\hline $\mathrm{U}-238$ & ICP-MS & $2.92 \mathrm{E}-07$ & $2.57 \mathrm{E}-06$ & $1.11 \mathrm{E}-06$ & $1.46 \mathrm{E}-06$ & $79.3 \%$ \\
\hline Np-237 & SGRS & $1.82 \mathrm{E}-06$ & $4.21 \mathrm{E}-06$ & $6.38 \mathrm{E}-07$ & $3.57 \mathrm{E}-06$ & $147.4 \%$ \\
\hline $\mathrm{Pu}-238$ & PuTTA & $1.35 \mathrm{E}-05$ & $5.70 \mathrm{E}-02$ & $9.12 \mathrm{E}-03$ & $4.79 \mathrm{E}-02$ & $144.8 \%$ \\
\hline $\mathrm{Pu}-239$ & S/ICP-MS & $4.24 \mathrm{E}-04$ & $3.03 \mathrm{E}-03$ & $1.06 \mathrm{E}-03$ & $1.97 \mathrm{E}-03$ & $96.3 \%$ \\
\hline $\mathrm{Pu}-240$ & S/ICP-MS & $1.54 \mathrm{E}-03$ & $8.09 \mathrm{E}-04$ & $2.48 \mathrm{E}-04$ & $5.61 \mathrm{E}-04$ & $106.1 \%$ \\
\hline $\mathrm{Pu}-241$ & PuTTA & $1.76 \mathrm{E}-05$ & $1.44 \mathrm{E}-02$ & $3.47 \mathrm{E}-03$ & $1.09 \mathrm{E}-02$ & $122.3 \%$ \\
\hline $\mathrm{Pu}-242$ & S/ICP-MS & $2.64 \mathrm{E}-05$ & $6.75 \mathrm{E}-07$ & $1.73 \mathrm{E}-07$ & $5.02 \mathrm{E}-07$ & $118.4 \%$ \\
\hline $\mathrm{Pu}-244$ & S/ICP-MS & Not Required & $<4.3 \mathrm{E}-10$ & $<1.9 \mathrm{E}-10$ & N/A & N/A \\
\hline $\mathrm{Cs}-137$ & GS & No Target & $7.65 \mathrm{E}-02$ & $3.41 \mathrm{E}-01$ & $-2.65 \mathrm{E}-01$ & $-126.7 \%$ \\
\hline Sr-90 & LSC & Not Required & $1.14 \mathrm{E}-01$ & $7.67 \mathrm{E}-02$ & $3.73 \mathrm{E}-02$ & $39.1 \%$ \\
\hline $\mathrm{Co}-60$ & GS & Not Required & $2.47 \mathrm{E}-05$ & $2.02 \mathrm{E}-05$ & $4.50 \mathrm{E}-06$ & $20.0 \%$ \\
\hline Am-241 & CR/GS & Not Required & $2.53 \mathrm{E}-03$ & $7.50 \mathrm{E}-04$ & $1.78 \mathrm{E}-03$ & $108.5 \%$ \\
\hline
\end{tabular}

Table 3-2. Tank 18F Wall Sample Concentration Results per g of Sampled Material

\begin{tabular}{|l|l|c|c|c|c|}
\hline \multicolumn{1}{|c|}{ Isotope } & $\begin{array}{c}\text { Analytical } \\
\text { Method }\end{array}$ & $\begin{array}{c}\text { Tk 18-1 (Upper } \\
\text { Wall) Ci/g }\end{array}$ & $\begin{array}{c}\text { SP4 (Lower } \\
\text { Wall) Ci/g }\end{array}$ & $\begin{array}{c}\text { Difference } \\
\text { Ci/g }\end{array}$ & $\begin{array}{c}\text { Percent } \\
\text { Difference }\end{array}$ \\
\hline U-233 & S/ICP-MS & $1.85 \mathrm{E}-09$ & $1.57 \mathrm{E}-09$ & $2.80 \mathrm{E}-10$ & $16.37 \%$ \\
\hline $\mathrm{U}-234$ & S/ICP-MS & $8.74 \mathrm{E}-09$ & $7.78 \mathrm{E}-09$ & $9.60 \mathrm{E}-10$ & $11.62 \%$ \\
\hline U-235 & S/ICP-MS & $1.06 \mathrm{E}-10$ & $1.01 \mathrm{E}-10$ & $5.00 \mathrm{E}-12$ & $4.83 \%$ \\
\hline $\mathrm{U}-236$ & S/ICP-MS & $3.99 \mathrm{E}-10$ & $3.03 \mathrm{E}-10$ & $9.60 \mathrm{E}-11$ & $27.35 \%$ \\
\hline $\mathrm{U}-238$ & ICP-MS & $2.46 \mathrm{E}-09$ & $2.47 \mathrm{E}-09$ & $-1.00 \mathrm{E}-11$ & $-0.41 \%$ \\
\hline Np-237 & SGRS & $4.03 \mathrm{E}-09$ & $1.42 \mathrm{E}-09$ & $2.61 \mathrm{E}-09$ & $95.78 \%$ \\
\hline $\mathrm{Pu}-238$ & PuTTA & $5.45 \mathrm{E}-05$ & $2.03 \mathrm{E}-05$ & $3.42 \mathrm{E}-05$ & $91.44 \%$ \\
\hline Pu-239 & S/ICP-MS & $2.90 \mathrm{E}-06$ & $2.36 \mathrm{E}-06$ & $5.40 \mathrm{E}-07$ & $20.53 \%$ \\
\hline $\mathrm{Pu}-240$ & S/ICP-MS & $7.74 \mathrm{E}-07$ & $5.51 \mathrm{E}-07$ & $2.23 \mathrm{E}-07$ & $33.66 \%$ \\
\hline $\mathrm{Pu}-241$ & PuTTA & $1.35 \mathrm{E}-05$ & $6.87 \mathrm{E}-06$ & $6.63 \mathrm{E}-06$ & $65.10 \%$ \\
\hline Pu-242 & S/ICP-MS & $6.46 \mathrm{E}-10$ & $3.84 \mathrm{E}-10$ & $2.62 \mathrm{E}-10$ & $50.87 \%$ \\
\hline $\mathrm{Pu}-244$ & S/ICP-MS & $<4.1 \mathrm{E}-13$ & $<4.2 \mathrm{E}-13$ & N/A & N/A \\
\hline Cs-137 & GS & $7.32 \mathrm{E}-05$ & $7.58 \mathrm{E}-04$ & $-6.85 \mathrm{E}-04$ & $-164.77 \%$ \\
\hline Sr-90 & LSC & $1.09 \mathrm{E}-04$ & $1.70 \mathrm{E}-04$ & $-6.10 \mathrm{E}-05$ & $-43.73 \%$ \\
\hline Co-60 & GS & $2.36 \mathrm{E}-08$ & $4.49 \mathrm{E}-08$ & $-2.13 \mathrm{E}-08$ & $-62.19 \%$ \\
\hline Am-241 & CR/GS & $2.43 \mathrm{E}-06$ & $1.67 \mathrm{E}-06$ & $7.60 \mathrm{E}-07$ & $37.07 \%$ \\
\hline
\end{tabular}


Recommendations for Assessing the Uncertainty in Tank 18-F Wall Samples

SRNL-STI-2010-00525

October 26, 2010

\section{Distribution}

S.P. Harris, 773-42A

W.L. Isom, Jr., 704-26F

R.C. Jolly, 704-70F

P.L. Lee, 773-42A

B.A. Martin, 705-1C

F.M. Pennebaker, 773-42A

G.D. Thaxton, IV, 704-70F 